\title{
Identification of Endogenous Sympathetic Neuron Pituitary Adenylate Cyclase-Activating Polypeptide (PACAP): Depolarization Regulates Production and Secretion through Induction of Multiple Propeptide Transcripts
}

\author{
Cynthia A. Brandenburg, Victor May, and Karen M. Braas \\ Department of Anatomy and Neurobiology, The University of Vermont, College of Medicine, Given Health Science \\ Complex, Burlington, Vermont 05405
}

\begin{abstract}
The vasoactive intestinal peptide/pituitary adenylate cyclaseactivating polypeptide (PACAP)/secretin/glucagon family of peptides displays numerous physiological roles in autonomic nervous system development and function. The regulated endogenous production and release of PACAP peptides in sympathetic neurons of the superior cervical ganglion (SCG) was investigated. The two posttranslationally processed forms of PACAP, PACAP27 and PACAP38, were identified in rat adult, neonatal, and cultured SCG neurons. PACAP38 levels were $\sim 5-10 \mathrm{fmol} /$ adult SCG and $\sim 2 \mathrm{fmol} /$ neonatal SCG; PACAP27 levels were comparable. The authenticity of peptide immunoreactivity in these tissues was verified by coelution with synthetic PACAP in reverse-phase HPLC analysis. Reverse transcription-PCR and sequence-specific hybridization revealed PACAP mRNA in adult, neonatal, and cultured SCG neurons; in situ hybridization histochemistry and immunocytochemistry localized the PACAP peptide and proPACAP mRNA to a subset of the SCG neuronal population. Basal and stimu-
\end{abstract}

lated release of endogenous PACAP38 from cultured sympathetic neurons was established, suggesting that these peptides may function as signaling molecules at target tissues. Chronic depolarization with $40 \mathrm{~mm}$ potassium stimulated the PACAP secretory rate 10 - to 20 -fold, with concomitant increases in cellular PACAP peptide and mRNA levels. When examined using Northern analysis, depolarizing conditions not only stimulated the $2.2 \mathrm{~kb}$ form of PACAP mRNA, but also induced the expression of a shortened, $0.9 \mathrm{~kb}$, transcript. Further reversetranscription PCR analysis demonstrated that this smaller transcript was not identical to the unique testicular message. These studies identify PACAP38 and PACAP27 as regulated endogenous releasable peptides contributing to the functional diversity and phenotypic plasticity of the sympathetic nervous system.

Key words: superior cervical ganglion; pituitary adenylate cyclase-activating polypeptide; PACAP; depolarization; sympathetic; autonomic; vasoactive intestinal peptide
Neuropeptides serve diverse functions as neurotransmitters, neuromodulators, and neurotrophic factors in the central and peripheral nervous systems. The vasoactive intestinal peptide (VIP)/ pituitary adenylate cyclase-activating polypeptide (PACAP)/ secretin/glucagon family of bioactive peptides has important physiological roles in autonomic neuron development, function, and target tissue regulation. PACAP peptides, the most recently identified members of this family, exist in two $\alpha$-amidated forms that arise from alternative posttranslational processing (Miyata et al., 1989; Ogi et al., 1990). PACAP38 has 38 amino acid residues [pro-PACAP(131-168)], whereas PACAP27 corresponds to the $\mathrm{N}$ terminus of PACAP38 [pro-PACAP(131-157)]. The relative levels of these two forms are tissue specific, although PACAP38 predominates in all tissues examined to date (Arimura et al.,

\footnotetext{
Received Feb. 18, 1997; accepted March 4, 1997.

This work was supported by American Heart Association Vermont Affiliate Grant 9506248S (K.M.B.), National Institutes of Health Grants HD-27468 and NS-01636 (V.M.), and National Science Foundation Grant DIR-9116229 (V.M. and K.M.B.). We thank Susan Harakall for excellent technical support, Ronald Emeson for plasmid construction, Peter Durda for oligonucleotide synthesis, Matthew Beaudet for assistance in the in situ hybridization studies, and Diane Jaworski for scientific discussions. Each author contributed equally to the design and execution of the studies and development of this manuscript.

Correspondence should be addressed to Dr. Karen M. Braas, Department of Anatomy and Neurobiology, The University of Vermont College of Medicine, Given Health Science Complex, Burlington, VT 05405.

Copyright (C) 1997 Society for Neuroscience $\quad 0270-6474 / 97 / 174045-11 \$ 05.00 / 0$
}

1991). PACAP peptides are abundant in specific regions of the nervous system, gastrointestinal tract, adrenal glands, and testes. In nervous tissues, the predominant form of pro-PACAP mRNA is $\sim 2.2 \mathrm{~kb}$, whereas a smaller $0.8 \mathrm{~kb}$ variant has been described in testes (Ogi et al., 1990; Ohkubo et al., 1992; Hurley et al., 1995). PACAP and VIP peptides activate at least three distinct receptors; only PACAP peptides exhibit high affinity for the type I PACAP-selective receptor, whereas VIP and PACAP have similar high affinities for the $\mathrm{VIP}_{1} / \mathrm{PACAP}$ and $\mathrm{VIP}_{2} / \mathrm{PACAP}$ receptors (Arimura, 1992; Ishihara et al., 1992; Hashimoto et al., 1993; Hosoya et al., 1993; Lutz et al., 1993; Morrow et al., 1993; Pisegna and Wank, 1993; Spengler et al., 1993; Svoboda et al., 1993; Inagaki et al., 1994). The tissue-specific responses to PACAP and VIP, however, result not only from the expression of distinct receptor types, but also from the activation of particular type I receptor isoforms. Whereas VIP/PACAP receptors are coupled solely to adenylyl cyclase, type I PACAP-selective receptor isoforms display unique patterns of adenylyl cyclase and phospholipase $\mathrm{C}$ activation which differ for PACAP27 and PACAP38 (Deutsch and Sun, 1992; Spengler et al., 1993; Rawlings, 1994). Accordingly, autonomic neuron and target tissue responses to PACAP and VIP arise from the actions of the specific complement of peptides at distinct receptor types and variants.

Numerous autonomic target tissues in the head and neck, including the pineal gland, salivary glands, iris, and cerebral vas- 
culature, are regulated potently by VIP and PACAP. PACAP stimulation of pineal melatonin synthesis, elicitation of cerebral vasorelaxation, and elevation of cerebral vessel and iris cAMP production (Simmoneaux et al., 1993; Kobayashi et al., 1994; Nilsson, 1994; Nilsson et al., 1994) is consistent with expression of multiple PACAP-selective and VIP/PACAP receptors in these tissues. The current studies investigate the expression of PACAP by SCG neurons as one potential source of this neuropeptidergic regulator of ganglionic and target tissue function. Endogenous sympathetic neuronal expression of PACAP27 and PACAP38 peptides and mRNA was identified, and PACAP release from primary cultured sympathetic neurons was demonstrated. Numerous sympathetic neurophysiological processes are modulated by depolarization, including the production and release of sympathetic neurotransmitters and neuropeptides (Rao et al., 1992a; Sun et al., 1992; Zigmond et al., 1992; Lewis et al., 1994; DeKoninck and Cooper, 1995; May et al., 1995). Therefore, this paradigm was chosen to further examine potential changes in PACAP expression under a well established regulatory influence. Depolarization not only increased SCG PACAP content, secretion, and mRNA expression, but also induced unexpectedly a novel form of PACAP mRNA transcript. These results implicate PACAP peptides in sympathetic nervous system regulation and demonstrate that sympathetic PACAP expression can be modulated, thus contributing to the neurophenotypic and functional diversity of sympathetic neurons.

\section{MATERIALS AND METHODS}

\section{Animals and tissues}

Adult male (225-250 g) and untimed pregnant female Sprague Dawley rats were obtained from Charles River. All animals were housed in the Given Animal Care Facility of the University of Vermont, and all protocols were approved by the Institutional Animal Care and Use Committee. Ganglia from mixed sex litters were obtained from neonatal (postnatal day 1) rats for cell culture. For biochemical analysis, adult and neonatal rats were killed by decapitation, and tissues were removed and frozen before extraction. Some ganglia from adult male Sprague Dawley rats were obtained from Zivic Miller Laboratories (Zelienople, PA).

\section{Cell culture}

Primary SCG neuron cultures were prepared as described previously (May and Braas, 1995; May et al., 1995). For each culture preparation, neonatal rat SCGs from three to five litters (35-60 animals; 70-120 ganglia) were enzymatically dispersed to produce a pooled population of cells. Cells were plated at an initial density of $1.5 \times 10^{4}$ neurons $/ \mathrm{cm}^{2}$ into $16 \mathrm{~mm}\left(2 \mathrm{~cm}^{2}\right)$ multiwell plates, treated with cytosine $\beta$-Darabinofuranoside to eliminate non-neuronal cells, and maintained in defined complete serum-free medium (May et al., 1995).

To examine the effects of depolarization, sympathetic neurons were cultured in the presence of $40 \mathrm{mM} \mathrm{KCl}$ in the complete serum-free medium; control cells were cultured in the same medium containing 40 $\mathrm{mm} \mathrm{NaCl}$. For each treatment paradigm, the neurons were incubated in a control $(\mathrm{NaCl})$ or depolarizing $(\mathrm{KCl})$ medium beginning on day 9 of culture; the medium containing $\mathrm{NaCl}$ or $\mathrm{KCl}$ was replaced each $24 \mathrm{hr}$. The cumulative levels of released PACAP were determined as the sum of the peptide released per well for each $24 \mathrm{hr}$ period within the specified treatment time. In peptide stability tests, $>80 \%$ of PACAP was quantitatively recovered $24 \mathrm{hr}$ after addition to cultured SCG neurons. For each experiment, replicate cultures from a single dissociation were used for control and depolarized neurons.

\section{PACAP peptide analysis}

Radioimmunoassay. Individual adult and neonatal SCGs were extracted in $5 \mathrm{~N}$ acetic acid containing $2 \mathrm{mg} / \mathrm{ml} \mathrm{BSA}$ and $0.3 \mathrm{mg} / \mathrm{ml} \mathrm{PMSF}$. The extracts were frozen and thawed, lyophilized, and resuspended in $100 \mathrm{~mm}$ sodium phosphate buffer, $\mathrm{pH} 7.4$, containing $50 \mathrm{~mm} \mathrm{NaCl}, 1 \mathrm{mg} / \mathrm{ml} \mathrm{BSA}$, and $0.1 \%$ Triton X-100 (RIA buffer). After treatment of cultured SCG neurons, the cells were extracted as described previously (May and Braas,
1995; May et al., 1995); the conditioned medium was recycled three times onto a $\mathrm{C}_{18}$ Sep-Pak solid-phase cartridge (Waters Associates, Milford, MA), washed with $9 \mathrm{ml}$ of $0.1 \%$ trifluoroacetic acid (TFA), and eluted with $3 \mathrm{ml}$ of $80 \%$ acetonitrile in $0.1 \%$ TFA (Bennett et al., 1981; Arimura et al., 1991). The eluate was dried under reduced pressure and resuspended in RIA buffer immediately before assay. Cellular, tissue, and secreted PACAP levels were determined by a modification of the double antibody radioimmunoassay reported previously (Braas et al., 1994a,b; May and Braas, 1995; May et al., 1995). Assays for PACAP38 and PACAP27 used antisera RIN8920 and RIN8922 (Peninsula Laboratories, Belmont, CA) and ${ }^{125}$ I-PACAP38(31-38) and ${ }^{125}$ I-PACAP27 (Peninsula Laboratories), respectively. The PACAP38 assay had a midpoint of $\sim 2.6 \mathrm{fmol}$; the maximum net binding was $23 \%$, and nonspecific binding was $2 \%$. The radioimmunoassay for PACAP27 demonstrated a midpoint of $2.7 \mathrm{fmol}$, and maximum net binding was $24 \%$, whereas nonspecific binding was $2 \%$. The cross-reactivity of the PACAP38 assay for PACAP27 was $0.01 \%$; the cross-reactivity of the PACAP27 assay with PACAP38 was $1 \%$. Recovery of the PACAP peptides from the Sep-Pak cartridges was $>95 \%$.

Reverse-phase HPLC. SCGs were homogenized in 1\% TFA, $1 \mathrm{M}$ hydrochloric acid, $5 \%$ formic acid, and $1 \%$ sodium chloride containing 15 $\mu \mathrm{g} / \mathrm{ml}$ PMSF, $16 \mu \mathrm{g} / \mathrm{ml}$ benzamidine, and $2 \mu \mathrm{g} / \mathrm{ml}$ leupeptin (Bennett et al., 1978). The samples were frozen, thawed, and centrifuged, the supernatants were cycled onto $\mathrm{C}_{18}$ Sep-Pak solid-phase extraction cartridges as described above, and the eluates were dried under reduced pressure.

Combined reversed-phase HPLC and radioimmunoassay were used to determine the authenticity of the peptide quantitated by radioimmunoassay. Samples were fractionated on a Pharmacia PC $3.2 / 3$ precision column prepacked with $\mu$-RPC C2/C18 using a TFA/acetonitrile solvent system (Bennett et al., 1981). Solvent A consisted of 0.1\% TFA, and solvent B contained $0.1 \%$ TFA in $80 \%$ acetonitrile. The peptides were eluted with a linear gradient from 0 to $30 \%$ solvent B over 5 min at a flow rate of $100 \mu \mathrm{l} / \mathrm{min}$, followed by a linear gradient from 30 to $45 \%$ solvent $\mathrm{B}$ over $45 \mathrm{~min}$ at a flow rate of $50 \mu \mathrm{l} / \mathrm{min}$. Twenty-five microliter fractions were collected and dried under reduced pressure for PACAP radioimmunoassay.

\section{Pro-PACAP $m R N A$ analysis}

$R N A$ purification. Total RNA was prepared using RNA STAT-60 total RNA/mRNA isolation reagent (Tel-Test B, Inc., Friendswood, TX) as described previously (Braas et al., 1994a,b; May and Braas, 1995). Poly $\left(\mathrm{A}^{+}\right)$RNA was isolated from total RNA using the Oligotex suspension spin column protocol (Qiagen, Inc., Chatsworth, CA).

Reverse transcription-PCR and sequence-specific hybridization. Firststrand cDNA was synthesized from total RNA using SuperScript II reverse transcriptase and oligo-dT primers with the SuperScript preamplification system (Life Technologies, Grand Island, NY). PCR was performed as described previously (May and Braas, 1995). Amplification was conducted using primers specific for the rat neuronal or testicular pro-PACAP transcripts (Table 1, see Fig. 9A) (Ogi et al., 1990; Hurley et al., 1995) or primers specific for the PACAP type I, VIP $/$ PACAP, and $\mathrm{VIP}_{2} /$ PACAP receptors (Table 1) (Spengler et al., 1993; May and Braas, $1995)$. The amplified products were resolved on $1.6 \%$ agarose gels, stained with ethidium bromide, and visualized with UV illumination.

Verification of the reverse transcription pro-PACAP PCR products was performed using sequence-specific hybridization. The amplified cDNA, fractionated on $1.6 \%$ agarose gels, was denatured, neutralized, and rapidly downward transferred to Nytran-Plus membrane (Schleicher $\&$ Schuell, Keene, NH). The membranes were prehybridized in $1.5 \times$ SSPE $(1 \times$ SSPE is $150 \mathrm{~mm} \mathrm{NaCl}, 10 \mathrm{~mm}$ monobasic sodium phosphate, pH 7.4, and 1.0 mm EDTA) containing $10 \%$ polyethylene glycol, $7 \%$ SDS and $200 \mu \mathrm{g} / \mathrm{ml}$ sheared salmon sperm DNA, and subsequently hybridized at $65^{\circ} \mathrm{C}$ for $48 \mathrm{hr}$ with the synthetic antisense internal oligonucleotide probe, 5'-TGGTCTGATCCCAGGGAAGCTGAGTCCGGCGGCAGGTGAACA-3', end-labeled with $\left[\gamma^{32} \mathrm{P}\right]$ ATP using T4 polynucleotide kinase (Promega, Madison, WI). The blots were washed and apposed to either x-ray film with an intensifying screen or REFLECTION autoradiography film and screen (DuPont NEN, Wilmington, DE).

Riboprobe synthesis. A $606 \mathrm{bp}$ fragment of rat pro-PACAP cDNA containing nucleotides 486-1071 (GenBank accession number M63006) was amplified by PCR and subcloned into pBluescript II $\mathrm{KS}^{-}$(Stratagene, La Jolla, CA). The construction was characterized by restriction analysis and sequencing. T3 and T7 polymerase were used to generate the antisense and sense riboprobes, respectively. Probes were labeled with $\left[\alpha^{-}{ }^{32} \mathrm{P}\right] \mathrm{UTP}$ (Amersham Corp., Arlington Heights, IL) for Northern 
Table 1. Reverse transcription-PCR gene-specific primers

\begin{tabular}{|c|c|c|c|c|c|}
\hline Oligo & Specificity & Sequence & Position* & $\begin{array}{l}\text { Annealing } \\
\text { temperature }\end{array}$ & $\begin{array}{l}\text { Product } \\
\text { size }(\mathrm{s})\end{array}$ \\
\hline \multirow{10}{*}{$\begin{array}{l}\text { PCP1 } \\
\text { PCP2 } \\
\text { PCP3 } \\
\text { PCP4 }\end{array}$} & \multirow{2}{*}{$\begin{array}{l}\text { Neuronal PACAP } \\
\text { transcript }\end{array}$} & 5'-ATGCCTCTCTGGTTGTGATTC-3' & $486-506$ & \multirow{2}{*}{$57^{\circ}$} & \multirow{2}{*}{$606 \mathrm{bp}$} \\
\hline & & 5'-CGCTATTCGGCGTCCTTTGTT-3' & $1071-1091$ & & \\
\hline & \multirow{2}{*}{$\begin{array}{l}\text { Testicular PACAP } \\
\text { transcript }\end{array}$} & 5'-GCATAAATTCGATTCAACACA-3' & $63-83$ & \multirow{2}{*}{$55^{\circ}$} & \multirow{2}{*}{$362 \mathrm{bp}$} \\
\hline & & 5'-CTGGGTAGTAAAGGGCGTAGG-3' & $404-424$ & & \\
\hline & \multirow{2}{*}{$\begin{array}{l}\text { PACAP type I } \\
\text { receptor }\end{array}$} & 5'-CTTGTACAGAAGCTGCAGTCCCCAGACATG-3' & 1078-1107 & \multirow{2}{*}{$60^{\circ}$} & $303 \mathrm{bp}$ \\
\hline & & 5'-CCGGTGCTTGAAGTCCATAGTGAAGTAACGGTTCACCTT-3' & $1342-1380$ & & $\begin{array}{l}38 / \mathrm{bp} \\
471 \mathrm{bp}\end{array}$ \\
\hline & \multirow{2}{*}{$\begin{array}{l}\mathrm{VIP}_{1} / \mathrm{PACAP} \\
\text { receptor }\end{array}$} & 5'-CGGCCACCCGACATTGGGAAG-3' & $1034-1054$ & \multirow{2}{*}{$61^{\circ}$} & \multirow{2}{*}{$323 \mathrm{bp}$} \\
\hline & & 5'-CTGCATGTGGCGCCGTTGCTG-3' & $1336-1356$ & & \\
\hline & \multirow{2}{*}{$\begin{array}{l}\mathrm{VIP}_{2} / \mathrm{PACAP} \\
\text { receptor }\end{array}$} & 5'-AAGCTAACTTCTCCAGATGTT-3' & $990-1010$ & \multirow{2}{*}{$55^{\circ}$} & \multirow{2}{*}{$396 \mathrm{bp}$} \\
\hline & & 5'-CAGCTAAATGACTGAGGTCTC-3' & $1365-1385$ & & \\
\hline
\end{tabular}

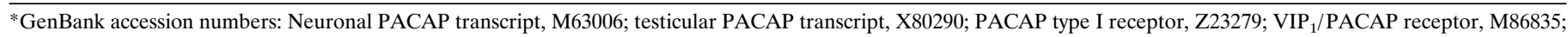
$\mathrm{VIP}_{2} /$ PACAP receptor, Z25885.

analysis and with digoxigenin (Boehringer Mannheim Biochemicals, Indianapolis, IN) for in situ hybridization histochemistry.

Northern blot analysis. The expression of specific pro-PACAP transcripts was determined using Northern blot analysis (May and Braas, 1995; Paquet et al., 1996) as modified below. The poly $\left(\mathrm{A}^{+}\right)$RNA generated was fractionated on $1.5 \%$ agarose gels containing $2.2 \mathrm{M}$

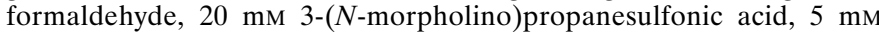
sodium acetate, and $1 \mathrm{~mm}$ EDTA, $\mathrm{pH} 7.0$, and downward transferred to a Nytran-Plus membrane using $20 \times$ SSC. The blots were prehybridized with $50 \%$ formamide, $5 \times \mathrm{SSC}, 1 \times \mathrm{PE}(1 \times \mathrm{PE}$ is $50 \mathrm{~mm}$ Tris $\mathrm{HCl}$, $\mathrm{pH} 7.5,0.1 \%$ sodium pyrophosphate, $1.0 \%$ SDS, $0.2 \%$ polyvinylpyrrolidone, $0.2 \%$ Ficoll-400, and $5 \mathrm{~mm}$ EDTA) and $200 \mu \mathrm{g} / \mathrm{ml}$ sheared salmon sperm DNA at $65^{\circ} \mathrm{C}$, and hybridized with $10^{6} \mathrm{cpm} / \mathrm{ml}\left[{ }^{32} \mathrm{P}\right] \mathrm{UTP}-$ labeled antisense riboprobe for $26 \mathrm{hr}$ at $65^{\circ} \mathrm{C}$. The blots were washed and apposed to REFLECTION autoradiography film with a REFLECTION intensifying screen for $9-120 \mathrm{hr}$ at $-85^{\circ} \mathrm{C}$.

\section{Morphological localization}

In situ hybridization histochemistry. Cryosections $(25 \mu \mathrm{m})$ of adult male SCGs were mounted on gelatin-chromalum-coated slides and processed for in situ hybridization histochemistry using the Genius uridine digoxigenin-antidigoxigenin technique (Boehringer Mannheim) as described previously (Braas et al., 1994b). Tissue sections were hybridized with digoxigenin-labeled sense or antisense pro-PACAP riboprobes for $24 \mathrm{hr}$ at $45^{\circ} \mathrm{C}$. The labeled neurons were visualized with anti-digoxigeninalkaline phosphatase using nitro blue tetrazolium and 5-bromo-4-chloro3 -indolyl-phosphate as phosphatase substrates in the presence of the isoform-selective alkaline phosphatase inhibitor levamisole $(1 \mathrm{~mm})$. The population of neurons expressing pro-PACAP mRNA was determined as described previously (Braas et al., 1983; 1994b; May and Braas, 1995; May et al., 1995).

Immunocytochemistry. Cultured sympathetic neurons were stained for PACAP immunoreactivity using the avidin-biotin-peroxidase complex technique as reported previously (Braas et al., 1994b; May et al., 1995). The cells were incubated with 1:10,000 guinea pig anti-PACAP38 (GHC8920; Peninsula Laboratories, Belmont, CA) for $24 \mathrm{hr}$ at $4^{\circ} \mathrm{C}$, washed, and processed as follows: 1:200 biotinylated goat anti-guinea pig IgG, $90 \mathrm{~min} ; 1: 200$ avidin-biotin-peroxidase complex (Vectastain Elite ABC kit, Vector Laboratories, Burlingame, CA), 90 min; diaminobenzidine and hydrogen peroxide were used as peroxidase reaction substrates. The numbers of stained cultured cells were determined as referenced above.

\section{Data analysis}

Student's $t$ test was used to determine differences between treatments. The significance of changes in cell content and secretion was evaluated; $p<0.05$ was considered significant. All values are expressed as mean \pm SEM. For data points without apparent error bars, the error bars are within the symbols. Each study used 3-12 individual samples per data point, and each study was repeated at least two or three times. Secretory rates were calculated using SigmaPlot for Windows version 2.0 software (Jandel Scientific, San Rafael, CA).

\section{RESULTS \\ Tissues innervated by the SCG express PACAP-selective receptors}

Many target tissues of the autonomic nervous system respond to the PACAP/VIP family of neuropeptides. The effects of PACAP and VIP are mediated by at least three receptor types; the type I PACAP receptors bind only PACAP peptides with high affinity, and the $\mathrm{VIP}_{1} / \mathrm{PACAP}$ and $\mathrm{VIP}_{2} / \mathrm{PACAP}$ receptors bind both PACAP and VIP with similar high affinity (Arimura, 1992; Rawlings, 1994). In assessing the ability of sympathetic targets in the head and neck to respond to these peptides, initial studies were performed to identify which receptor-encoding transcripts are expressed by specific tissues. Reverse transcription-PCR revealed the presence of mRNA-encoding isoforms of the type I PACAPselective receptor in the pineal, submaxillary, and sublingual glands, iris, and cerebral blood vessels (Fig. 1), consistent with the actions of PACAP peptides in these tissues. Tissue-specific expression of mRNA for one or both of the PACAP/VIP nonselective VIP receptors was also observed. Because postganglionic SCG neurons represent one source of innervation to these tissues, additional investigations were performed to examine whether the PACAP peptides are among other neuropeptidergic regulators produced by the SCG.

\section{PACAP immunoreactivity is expressed endogenously by sympathetic neurons}

To evaluate whether rat SCGs store PACAP peptides, endogenous peptide levels were determined by radioimmunoassay using antisera specific for either PACAP38 or PACAP27. Both structural forms of the peptide were identified in adult and neonatal ganglia (Fig. 2). Adult SCGs contained $\sim 4.8$ fmol of PACAP38 immunoreactivity/ganglion. The levels of PACAP27 immunoreactive material were $6.7 \mathrm{fmol} /$ ganglion, which was slightly higher than those for PACAP38. In neonatal (day 1 postnatal) SCGs, the levels of PACAP38 and PACAP27 immunoreactivity were lower than those measured in the adult ganglia and represented $\sim 2 \mathrm{fmol}$ of each peptide/ganglion (Fig. 2). The relative equal abundance of PACAP38 and PACAP27 in the SCG contrasts with other tissues 
Figure 1. Tissues innervated by the SCG differentially express isoforms of the type I PACAP-selective $(P A C A P R), \mathrm{VIP}_{1} / \mathrm{PACAP}$ $(V I P 1 R)$ and $\mathrm{VIP}_{2} /$ PACAP $(V I P 2 R)$ receptors. Total RNA from individual adult male rat pineal, sublingual, and submaxillary glands; iris; and cerebral blood vessels was reversetranscribed, and the cDNA was amplified using primers flanking the insertion site of the alternative splice variants of the type I PACAP receptor or primers specific for each of the VIP/PACAP receptors (Table 1). The amplified products and a $100 \mathrm{bp}$ DNA ladder were resolved on $1.6 \%$ agarose gels, stained with ethidium bromide, and visualized by UV illumination. The predicted sizes of the products are 303,387 , and $471 \mathrm{bp}$ for the type I PACAP receptor variants containing neither, one, and both 84 bp cassettes, respectively, and 323 and $396 \mathrm{bp}$ for the $\mathrm{VIP}_{1} / \mathrm{PACAP}$ and $\mathrm{VIP}_{2} / \mathrm{PACAP}$ receptors.

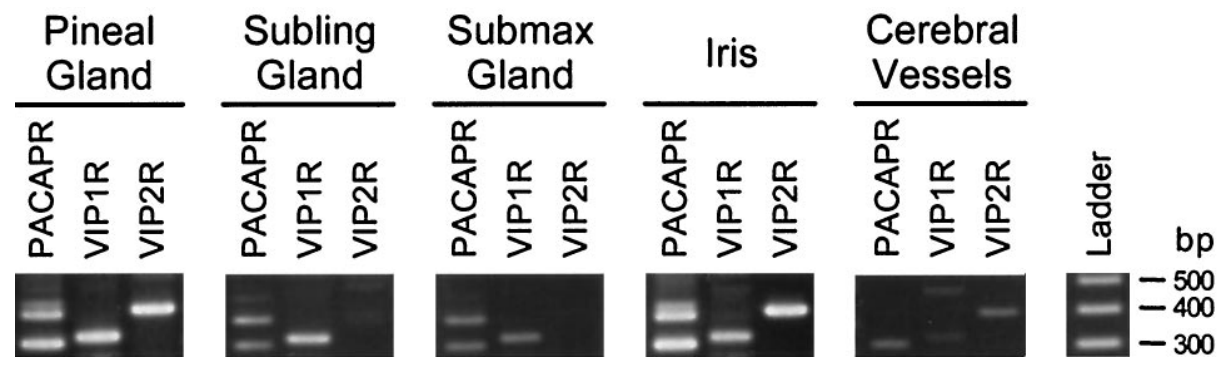

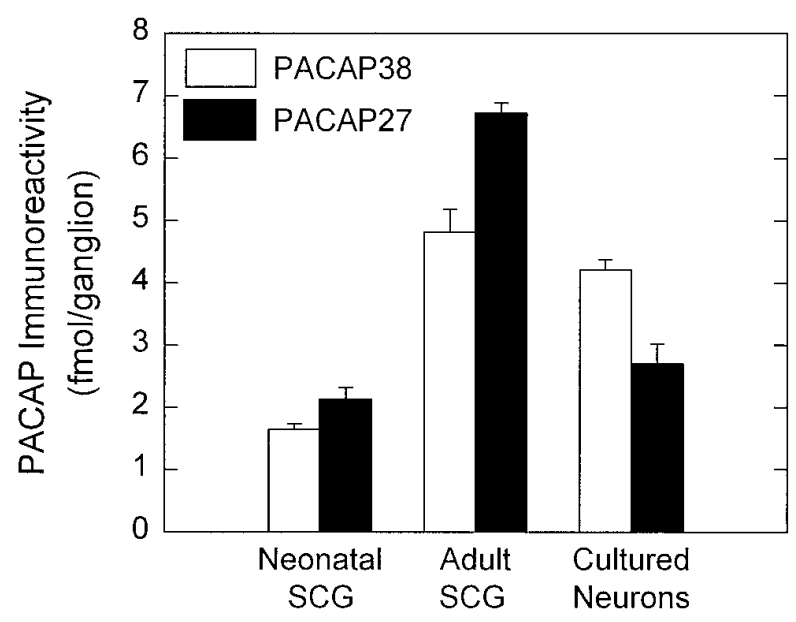

Figure 2. PACAP38 and PACAP27 immunoreactivities are expressed endogenously by SCGs neurons. Individual adult and neonatal (postnatal day 1) rat SCG were extracted for peptide level analysis. Dissociated SCG neurons, plated at an initial density of $1.5 \times 10^{4}$ cells $/ \mathrm{cm}^{2}$ into $16 \mathrm{~mm}$ dishes $\left(2 \mathrm{~cm}^{2}\right)$, were cultured in defined medium for $9 \mathrm{~d}$ and harvested for assay. Endogenous pro-PACAP peptide levels were determined by radioimmunoassay using antisera specific for PACAP38 (open bar) or PACAP27 ( filled bar). Data represent the mean femtomoles of PACAP immunoreactivity per ganglion or ganglion equivalent $(26,000$ cultured neurons) $\pm \operatorname{SEM}(n=10-12$ for each preparation and peptide).

examined to date in which the longer form of the peptide predominates (Arimura et al., 1991).

To verify that the immunoreactivity measured by the assays reflected authentic PACAP, reverse-phase HPLC analysis was performed. Adult ganglia tissue extracts were fractionated on a C2/C18 column using a TFA/acetonitrile solvent system and were subsequently examined by radioimmunoassay. The PACAP38 immunoreactive material eluted at the same retention time as synthetic PACAP38 (Fig. 3). Greater than $90 \%$ of the PACAP38 immunoreactivity observed in the adult rat SCG tissue extracts was recovered in the HPLC PACAP38 fractions, confirming that the PACAP38 immunoreactive material in the ganglia, as measured by radioimmunoassay, represented authentic peptide. The peak of PACAP38 immunoreactivity from neonatal SCG extracts also coeluted with synthetic PACAP38 (data not shown).

Although PACAP peptide immunoreactivities were present in both adult and neonatal SCG extracts, the sources of the peptides within the ganglia remained unclear. To identify whether PACAP immunoreactive material was derived specifically from sympathetic neurons rather than from other sources such as preganglionic nerve terminals, glial cells, supporting tissue, or plasma, PACAP levels were examined also in dissociated SCG neurons maintained under long-term culture conditions devoid of potential extraneous sources of PACAP. Cultures enriched for principal neurons were maintained under serum-free, defined medium conditions; after $13 \mathrm{~d}$ of culture, cell extracts contained $\sim 4.2 \mathrm{fmol} /$ ganglion equivalent (based on 26,000 neurons per ganglion; Purves et al., 1986) or $\sim 1.6 \mathrm{fmol}$ PACAP38 immunoreactivity $/ 10^{4}$ neurons (Fig. 2). These levels of PACAP38 represented a greater than twofold increase from the intact neonatal tissue levels and were comparable to the amounts observed in adult ganglia. In contrast, the levels of cellular PACAP27 in cultured neurons were similar to those observed in neonatal SCGs and represented only $40 \%$ of adult SCG levels; cell extracts contained $2.7 \mathrm{fmol}$ of PACAP27/ganglion equivalent or $\sim 1.0 \mathrm{fmol} / 10^{4}$ cells. The persistence of PACAP peptide immunoreactivities in cultured sympathetic neurons strongly supports endogenous production of PACAP by principal neurons of the SCG. A detailed evaluation of neuronal PACAP38 content throughout $15 \mathrm{~d}$ of culture revealed that the greater than twofold increase in PACAP immunoreactive material developed gradually with time (data not shown).

To demonstrate that the PACAP immunoreactivity was localized to principal sympathetic neurons, cultures were stained immunocytochemically using an antibody against PACAP38. PACAP was localized to a subpopulation of sympathetic neurons, and staining was prominent in both cell bodies and neuronal processes (Fig. 4A-C). The perikarya of the principal SCG neurons were stained heterogenously; a small population of isolated cells demonstrated moderate to intense cytoplasmic labeling (Fig. $4 A-C)$. Cellular staining often extended into neuronal processes, which could be followed as distinct individual fibers, and expanded varicosities along the fiber tracts (Fig. 4B, arrowheads). The number of PACAP immunoreactive cells represented $\sim 7 \%$ of the total culture neuronal population, whereas $56 \%$ of the neurons expressed NPY and $>90 \%$ contained tyrosine hydroxylase immunoreactivity (May et al., 1995); a small population of PACAP containing neurons in these cultures also expressed NPY immunoreactivity. The population of cultured neurons expressing PACAP immunoreactivity was similar to that observed for prin- 


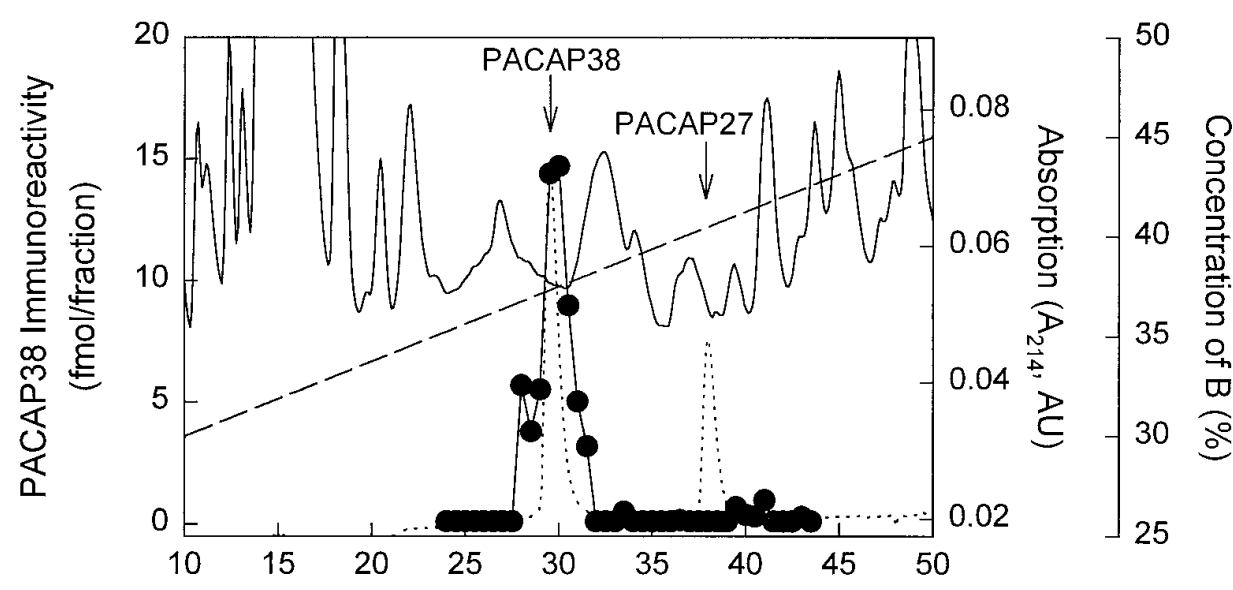

Retention Time (min)
Figure 3. SCG PACAP immunoreactivity represents authentic peptide. Adult SCG extracts were analyzed by combined reversephase HPLC and radioimmunoassay. Samples were fractionated on a $\mu \mathrm{RPC} 3.2 / 3 \mathrm{C} 2 / \mathrm{C} 18$ column using a TFA/acetonitrile gradient solvent system as described in Materials and Methods. At a flow rate of $50 \mu \mathrm{l} / \mathrm{min}, 25 \mu \mathrm{l}$ fractions were collected. The fractions subsequently were processed and assayed for PACAP38 immunoreactivity. Solid line, UV absorbance at $214 \mathrm{~nm}$ of SCG extract; dotted line, UV elution profile of synthetic PACAP38 and PACAP27 (300 ng each); -—, SCG extract PACAP38 immunoreactivity (fmol/fraction); dashed line, concentration gradient of solvent B $(0.1 \%$ TFA $/ 80 \%$ acetonitrile).
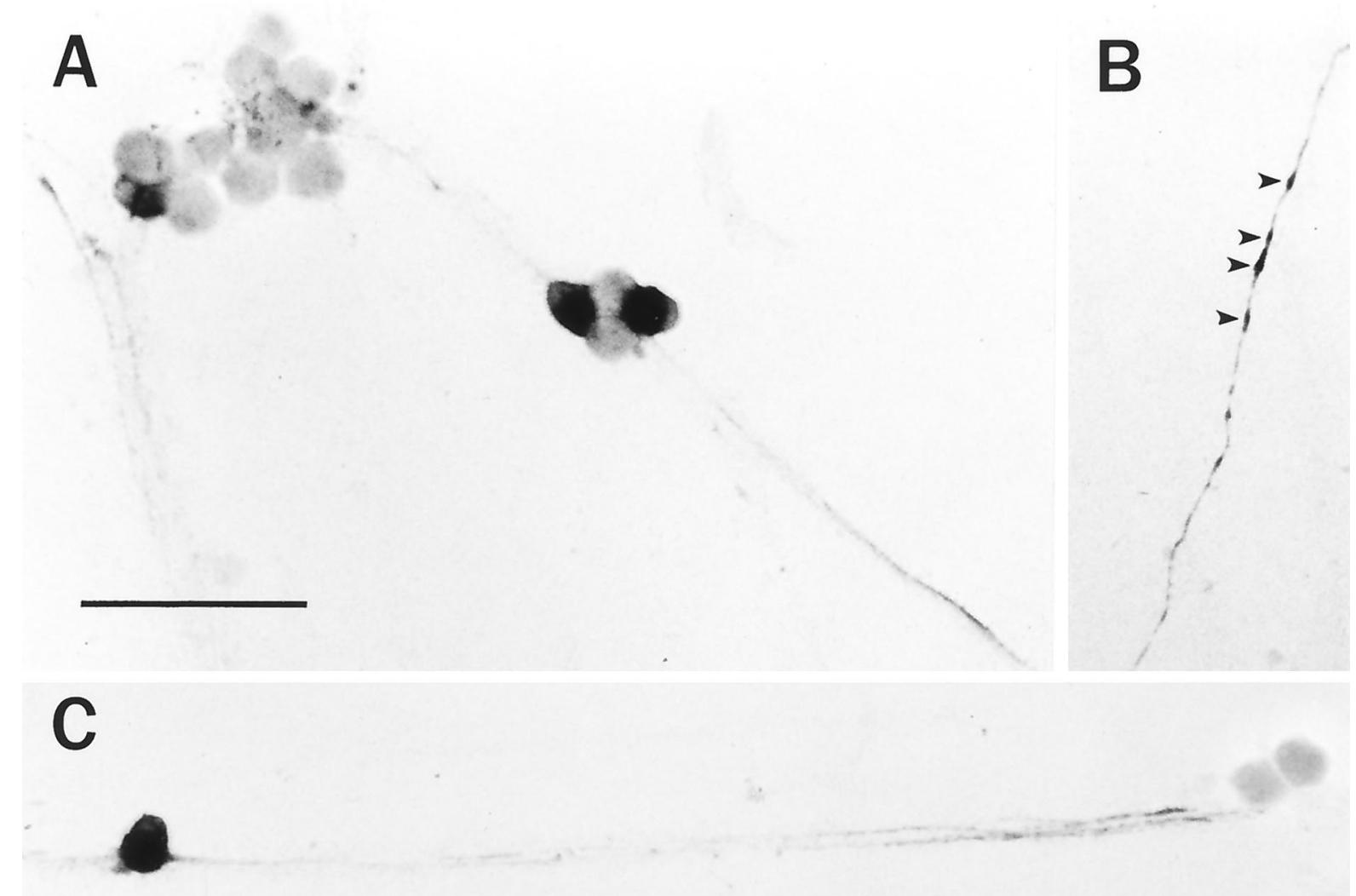

Figure 4. PACAP immunoreactivity is localized to a small population of sympathetic neurons in vitro. SCG neurons, cultured for 9 d, were fixed with $4 \%$ paraformaldehyde and stained immunocytochemically with 1:10,000 anti-PACAP38 using the avidin-biotin-peroxidase complex technique $(A-C)$. A subpopulation of neurons was stained heterogeneously, and PACAP38 immunoreactivity was localized to the processes, varicosities (arrowheads), and soma of a distinct population of neurons. Scale bar, $100 \mu \mathrm{m}$.

cipal neurons in the intact SCG (Klimaschewski et al., 1996; Sundler et al., 1996).

\section{SCG neurons express pro-PACAP mRNA}

The identification of PACAP immunoreactivities in the SCG and cultured neurons was consistent with endogenous PACAP production in the ganglion. For endogenous synthesis of the PACAP peptides to occur, mRNA encoding the PACAP precursor molecule must also be expressed in the sympathetic neurons. Accordingly, the PACAP biosynthetic capability of the SCG was examined using reverse transcription-PCR. Total RNA from neonatal and adult ganglia and cultured sympathetic neurons was reversetranscribed, and the cDNA was amplified using oligonucleotide primers specific for the neuronal pro-PACAP transcript (Table 1) 
Figure 5. Sympathetic neurons express pro-PACAP mRNA. Total RNA from individual adult and neonatal SCGs, and sympathetic neuronal cultures $\left(2 \mathrm{~cm}^{2}\right.$ wells) was reverse-transcribed, and the cDNA was amplified for 35 cycles using primers PCP1 and PCP2 (Table 1), which are specific for the rat neuronal pro-PACAP transcript. The identity of the neuronal pro-PACAP reverse transcription-PCR products was verified using sequence-specific hybridization. For product identification, the amplified products were transferred to a nylon membrane and hybridized with an internal oligonucleotide end-labeled with $\left[\gamma^{32} \mathrm{P}\right]-$ ATP. The predicted $606 \mathrm{bp}$ product identified by gene-specific probe hybridization of the amplified products is indicated.

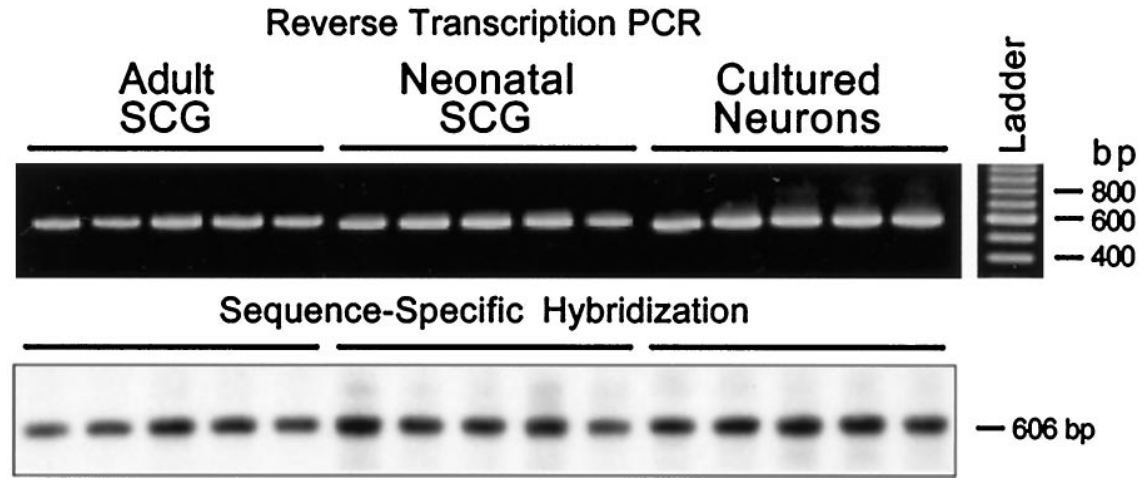

(Ogi et al., 1990). When the amplified products from individual ganglia or neuronal cultures were separated by agarose gel electrophoresis and visualized with ethidium bromide staining, PACAP precursor transcripts were identified in adult, neonatal, and cultured SCG neurons. A single amplified 606 bp product identical to the predicted size was observed in the three SCG preparations (Fig. 5). No amplified products were observed when either the reverse transcriptase or cDNA was omitted from the amplification reaction (data not shown). The identity of the reverse transcription-PCR products was verified using sequencespecific hybridization. The amplified PACAP products were transferred to a nylon membrane and hybridized with a radiolabeled synthetic antisense oligonucleotide probe that recognized a sequence internal to the PACAP primer templates. Gene-specific probe hybridization of the amplified products from adult and neonatal SCGs and cultured SCG neurons under stringent hybridization and washing conditions produced a single band of the predicted size (Fig. 5), further establishing the expression of PACAP mRNA in the different sympathetic neuronal preparations.

In contrast with PACAP peptide immunoreactivity, proPACAP mRNA is localized primarily to the neuronal cell bodies, allowing easy and direct morphological localization of PACAP expression in the intact SCG. Inhibition of axonal transport with colchicine to facilitate immunocytochemical staining of neuropeptides in the ganglia was not expedient, because colchicine alone induces neuronal PACAP expression (Hannibal et al., 1995). To identify the subpopulation of neurons expressing pro-PACAP mRNA in the SCG, in situ hybridization histochemistry was performed using digoxigenin-labeled pro-PACAP riboprobes. When adult rat SCG cryosections were hybridized with antisense proPACAP riboprobes, a restricted hybridization pattern was observed (Fig. 6A). A minor population (5-7\%) of the principal neurons was labeled, similar to the number of cultured neurons labeled immunocytochemically; incubation of adjacent tissue sections with sense riboprobes failed to produce detectable signals (Fig. 6B).

\section{Sympathetic neurons release PACAP in response to depolarization}

An essential characteristic of bioactive peptides mediating neuronal communication is release in response to specific signals. In considering a physiological role for PACAP as a neuromodulator in the sympathetic system, it is important to establish whether the PACAP immunoreactive material represents a releasable neuropeptide pool. A basal sympathetic neuronal PACAP secretory rate was determined by analysis of culture medium conditioned by SCG neurons. The cumulative PACAP38 immunoreactivity re-

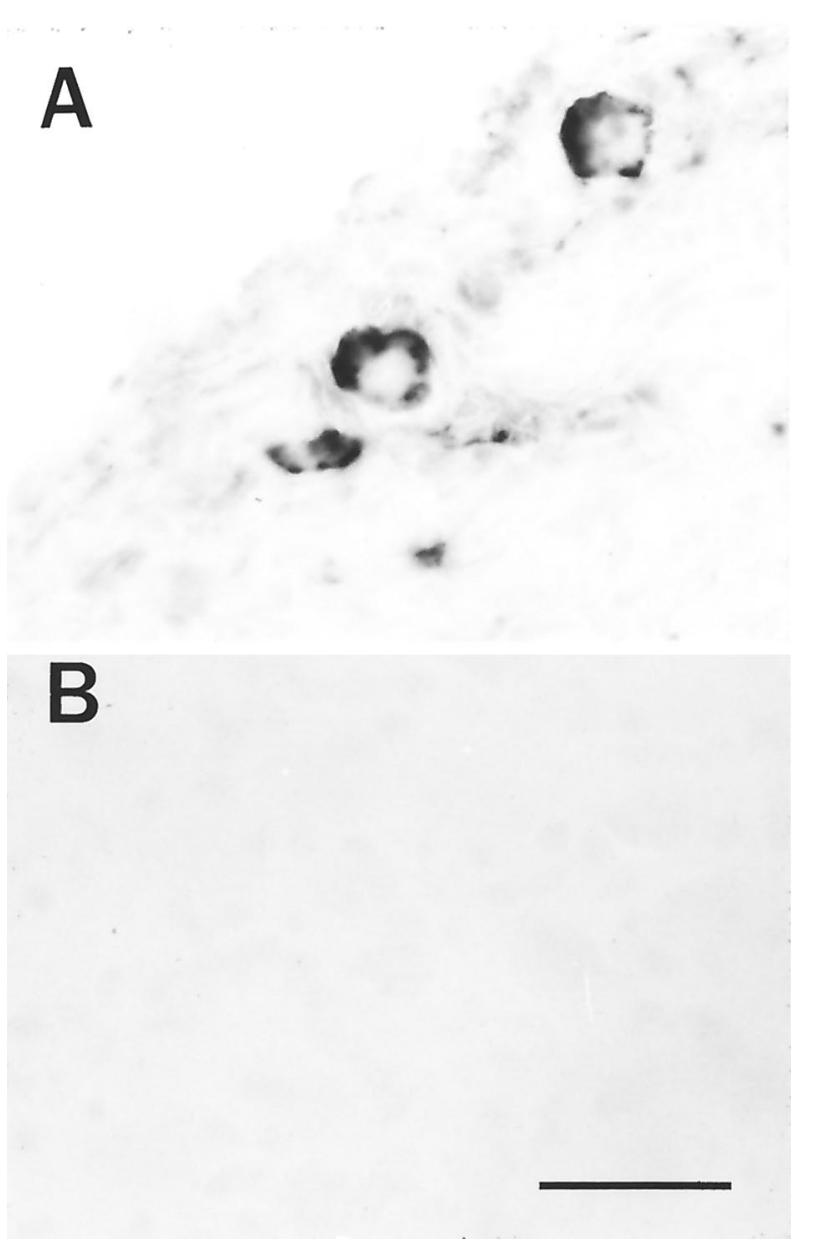

Figure 6. PACAP mRNA is localized to a subpopulation of sympathetic neurons in vivo. In situ hybridization histochemistry using antisense $(A)$ and sense $(B)$ digoxigenin-labeled PACAP riboprobes was performed on adult male SCG cryosections as described in Materials and Methods. After incubation with antidigoxigenin alkaline phosphatase, sections were processed with nitro blue tetrazolium and 5-bromo-4-chloro-3indolylphosphate as phosphatase substrates. Scale bar, $50 \mu \mathrm{m}$.

leased into medium conditioned by sympathetic neurons was $\sim 0.01 \mathrm{fmol} / 10^{4}$ cells $/$ hr (Fig. 7 , control), whereas PACAP immunoreactive material was undetectable in the serum-free defined medium in the absence of cells. The PACAP secretory rate remained constant throughout $18 \mathrm{~d}$ of cell culture (data not 


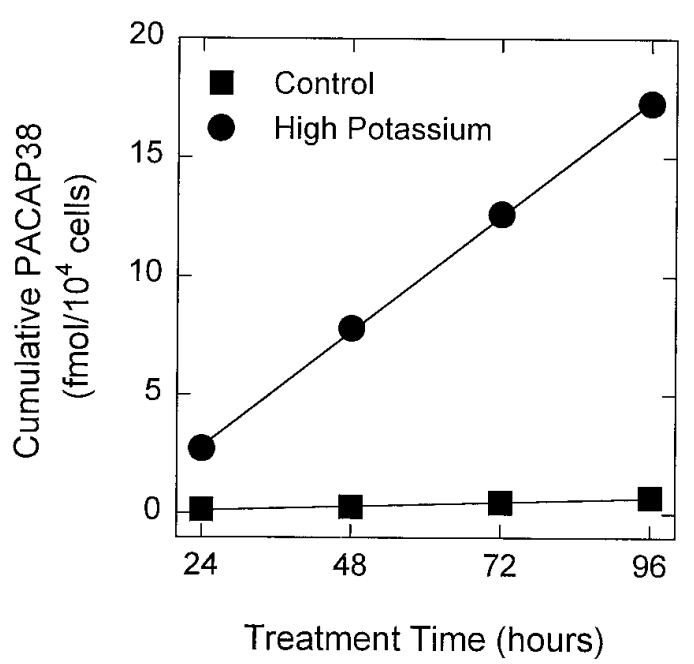

Figure 7. Depolarization stimulates sympathetic neuron PACAP release. SCG neurons were dissociated enzymatically and plated at an initial density of $1.5 \times 10^{4}$ cells $/ \mathrm{cm}^{2}$ onto $16 \mathrm{~mm}\left(2 \mathrm{~cm}^{2}\right)$ dishes. On day 9 of culture, the sympathetic neurons were incubated in $500 \mu \mathrm{l}$ of defined medium containing $40 \mathrm{~mm} \mathrm{NaCl}$ (control, $\mathbf{\square})$ or $40 \mathrm{~mm} \mathrm{KCl}$ (high potassium, -) for $96 \mathrm{hr}$. Every $24 \mathrm{hr}$, the conditioned medium was collected for PACAP38 radioimmunoassay, and replaced with fresh medium containing $\mathrm{NaCl}$ or $\mathrm{KCl}$. Data represent the mean cumulative femtomoles of PACAP38 immunoreactivity per $10^{4}$ cells \pm SEM $(n=3-6$ samples $)$. Error bars are within the symbols.

shown). The basal secretory rate represented $0.7 \%$ of total cellular PACAP38 content per hour, which was comparable to NPY secretory rates during early SCG culture periods and hormones from cultured endocrine cells (May and Eipper, 1986; May et al., 1995).

To ascertain whether SCG neuronal PACAP release could be stimulated by a specific signal such as depolarization, cells were maintained in defined medium containing either $40 \mathrm{mM} \mathrm{NaCl}$ (control) or $\mathrm{KCl}$ (depolarized) for four consecutive $24 \mathrm{hr}$ periods, and the cumulative secreted PACAP38 levels were determined. Elevated potassium concentrations stimulated PACAP38 release over 25-fold compared with parallel control cultures (Fig. 7). The depolarization-mediated increase in PACAP38 release was sustained throughout the $96 \mathrm{hr}$ treatment and represented 0.20 $\mathrm{fmol} / 10^{4}$ cells $/ \mathrm{hr}$. Neurons cultured in defined medium (untreated) or in a medium containing elevated sodium concentrations (40 $\mathrm{mM} \mathrm{NaCl}$; control) displayed identical basal rates of PACAP release.

\section{Neuronal intracellular PACAP levels are increased by depolarization}

Cellular levels of a number of sympathetic peptides, including VIP and substance $\mathrm{P}$, are modulated by neuronal depolarization (Kessler, 1984; Sun et al., 1992; Hyatt-Sachs et al., 1993; Mohney et al., 1994). To determine whether neuronal PACAP content was increased in parallel with secretion after chronic $(96 \mathrm{hr})$ depolarization, cell extracts were assayed for PACAP38 immunoreactivity. Peptide levels in depolarized cells were increased $\sim 15$-fold over control; cellular PACAP38 content was elevated significantly from control levels of $\sim 1.1 \mathrm{fmol} / 10^{4}$ cells to $15 \mathrm{fmol} / 10^{4}$ cells after depolarization $(p<0.0001)$. The population of PACAP immunoreactive neurons increased to $\sim 35 \%$ (five-fold over control) after potassium treatment; thus, the elevated PACAP levels most likely reflected an increase in both the number of neurons expressing the peptide and the amount of peptide per cell.

\section{Depolarization stimulates sympathetic neuronal PACAP through induction of multiple pro-PACAP transcripts}

To assess whether these changes in secretion and cellular content reflected, in part, an increase in cellular pro-PACAP mRNA expression, Northern blot analysis was performed in a parallel set of cultured neurons. Poly $\left(\mathrm{A}^{+}\right)$RNA from control and depolarized neurons was separated on denaturing gels, blotted, and hybridized to a radiolabeled pro-PACAP riboprobe; representative autoradiograms are shown in Figure 8 . The predominant transcript expressed by control sympathetic neuron cultures was a $2.2 \mathrm{~kb}$ form of pro-PACAP mRNA, which represented the principal form of pro-PACAP mRNA reported in other nervous system regions, including the hypothalamus (Ghatei et al., 1993; Hurley et al., 1995). Depolarization of the sympathetic neurons elicited a 15 -fold increase in the $2.2 \mathrm{~kb}$ pro-PACAP transcript; autoradiographic film exposure times that optimized the signals for the potassium-treated culture pro-PACAP mRNA failed to produce detectable signals in the control samples (Fig. 8).

Unexpectedly, the depolarization paradigm also potently induced a smaller, $0.9 \mathrm{~kb}$, pro-PACAP transcript (Fig. 8). The appearance of the $0.9 \mathrm{~kb}$ mRNA under depolarizing conditions could result from the induction of the previously reported testicular form of pro-PACAP mRNA. The distinctive testicular message is characterized by truncation of the 5'- and 3 '-untranslated regions of the neuronal message and addition of a unique 126-bp sequence to the $5^{\prime}$-terminus (Fig. 9A; Hurley et al., 1995). To examine whether the smaller message induced by depolarization in sympathetic neurons was the testicular form of pro-PACAP mRNA, reverse transcription-PCR, using primer templates specific for the testicular and neuronal forms of the message, and sequence-specific hybridization were performed. When cDNA from control and depolarized cultured sympathetic neurons was amplified with primers PCP1 and PCP2, which are specific for the neuronal transcript, the expected 606 bp product observed in the hypothalamus was obtained (Fig. 9). Amplification of testicular cDNA with testicular pro-PACAP mRNA-specific primers PCP3 and PCP4 produced the anticipated $362 \mathrm{bp}$ product. No products were obtained, however, when control and depolarized SCG neuronal cDNA was amplified using the testicular transcript-specific primers. These results suggested that the $0.9 \mathrm{~kb}$ PACAP mRNA expressed in elevated potassium neuronal cultures was most likely not caused by the induction of the testicular form of the message but may arise instead by other mechanisms, including usage of an alternative polyadenylation signal leading to shortening of the 3 '-untranslated region.

\section{DISCUSSION}

The current studies demonstrate that sympathetic neurons of the rat SCG produce a releaseable pool of PACAP peptides that is regulated by depolarization. Both PACAP27 and PACAP38 immunoreactivities were identified in adult and neonatal SCGs and neurons in culture. Total PACAP peptide (PACAP38 plus PACAP27) levels in adult SCGs were $6.6 \mathrm{pmol} / \mathrm{gm}$ tissue wet weight, which were among the highest tissue concentrations for PACAP reported. The hypothalamus contains the highest amount of PACAP published to date; total hypothalamic PACAP levels are $\sim 20$-fold higher than SCG levels or $130 \mathrm{pmol} / \mathrm{gm}$ wet weight (Arimura et al., 1991). SCG total PACAP levels were comparable to a number of neuroendocrine tissues that display the next highest levels, including the adrenal gland, cerebral cortex, hippocampus, posterior pituitary gland, and testes, in which peptide 


\begin{abstract}
Figure 8. Depolarization induces multiple pro-PACAP mRNA levels. Regulation of cellular pro-PACAP mRNA expression was evaluated by Northern blot analysis. SCG neurons were incubated in medium containing $40 \mathrm{~mm}$ $\mathrm{NaCl}\left(-K^{+}\right)$or $40 \mathrm{~mm} \mathrm{KCl}\left(+K^{+}\right)$for $96 \mathrm{hr}$ beginning on day 9 of culture. Poly $\left(\mathrm{A}^{+}\right) \mathrm{RNA}$ was isolated from total RNA from $1.8 \times 10^{5}$ sympathetic neurons, separated on denaturing gels, transferred to a nylon membrane, and hybridized to a pro-PACAP-specific radiolabeled riboprobe. Representative autoradiograms are shown $(n=4)$. Hybridization to the pro-PACAP transcripts was examined at shorter $(9 \mathrm{hr})$ and longer $(114 \mathrm{hr})$ film exposure times. Two micrograms of poly $\left(\mathrm{A}^{+}\right)$ mRNA from hypothalamus (Hypo) and testes were analyzed for pro-PACAP mRNA in parallel and exposed to film for $39 \mathrm{hr}$.
\end{abstract}

Figure 9. Reverse transcription-PCR and genespecific hybridization reveal that the smaller proPACAP transcript induced in SCG neurons is not the testicular form of the message. A, Schematic representation of the neuronal and testicular proPACAP transcripts demonstrating the positions of the transcript-specific oligonucleotide primer pairs; the neuronal pro-PACAP transcript-specific primers are PCP1 and PCP2 and the testicular pro-PACAP transcript-specific primers are PCP3 and PCP4 (Table 1). White, coding region; black, 5' untranslated region; gray, $3^{\prime}$-untranslated region; hatched, testes-specific $5^{\prime}$-untranslated region. $B$, Total RNA from individual SCG neuronal cultures incubated in medium containing $40 \mathrm{~mm} \mathrm{NaCl}$ $\left(-K^{+}\right)$or $40 \mathrm{mM} \mathrm{KCl}\left(+K^{+}\right)$was reversetranscribed, and the cDNA was amplified using the neuronal transcript-specific primers $(P C P 1$ and $P C P 2)$ or the testicular transcript-specific primers (PCP3 and PCP4). Total hypothalamic (Hypo) and testicular (Testes) RNA were reverse-transcribed and amplified with the neuronal and testicular primer pairs, respectively. The amplified products were fractionated, blotted, and hybridized with a radiolabeled synthetic internal oligonucleotide probe located within the pro-PACAP coding region that is identical for the neuronal and testicular transcripts; the membranes were apposed to film for $150 \min$ ( $S C G$ neurons $\pm \mathrm{K}^{+}$, both primer pairs), $70 \mathrm{~min}$ (hypothalamus), or $40 \mathrm{~min}$ (testes). The predicted product sizes are $606 \mathrm{bp}$ for the neuronal transcript-specific primers and $362 \mathrm{bp}$ for the testicular transcript-specific primers. Representative samples are shown; identical results were obtained from two independent culture preparations consisting of four to six individual sympathetic culture wells for each treatment.
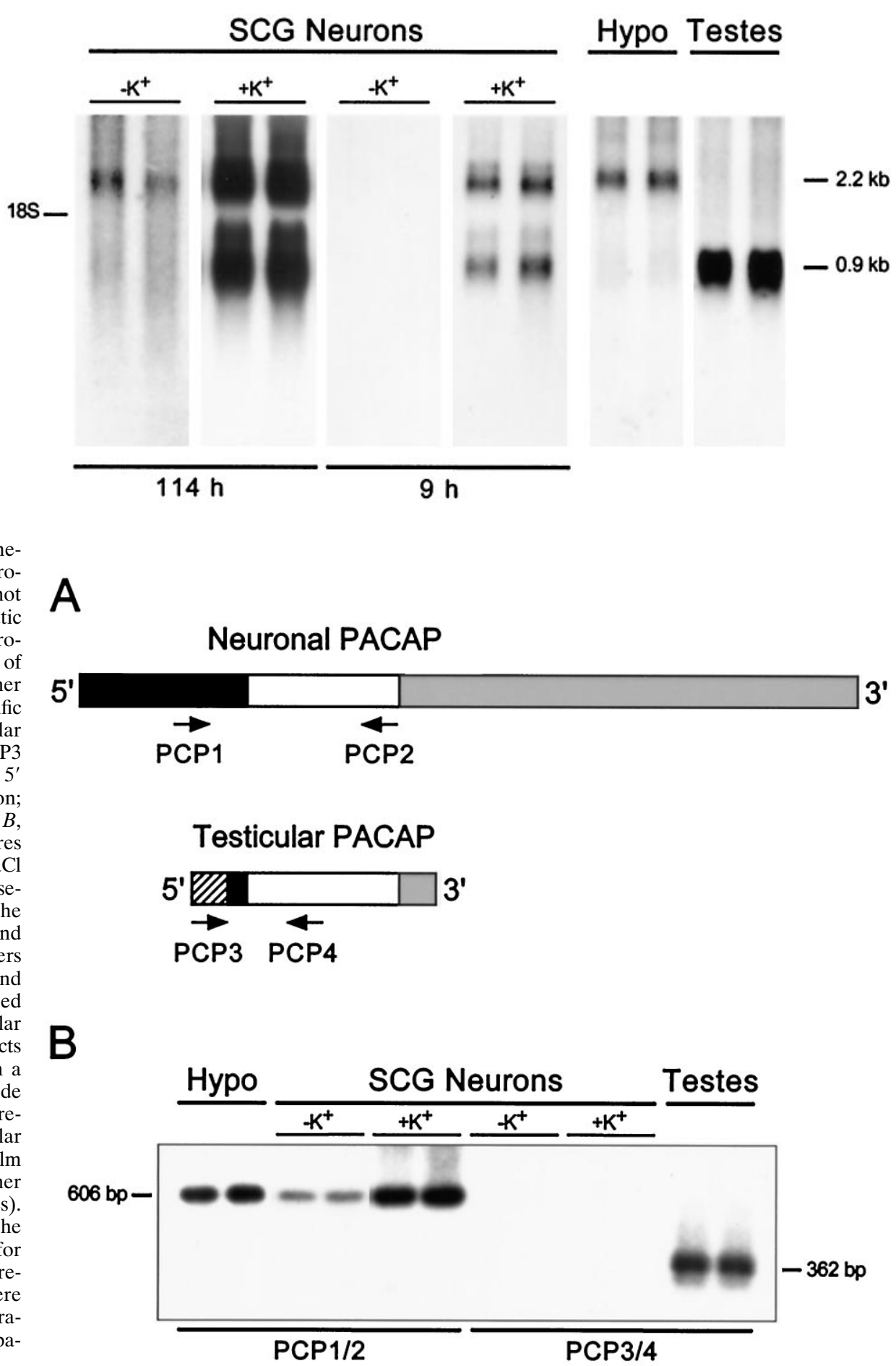

levels range from 3.2 to $12 \mathrm{pmol} / \mathrm{gm}$ wet weight (Arimura et al., 1991).

Unlike previously examined tissues, the SCG displayed similar levels of PACAP38 and PACAP27. Adult and neonatal SCG PACAP27 constituted $\sim 140$ and $\sim 130 \%$ of the PACAP38 levels (moles per gram tissue wet weight), respectively. In other tissues, the highest proportion of PACAP27 is observed in the heart atrium, where PACAP27 is $\sim 60 \%$ of the PACAP38 levels. Whereas PACAP27 represents $\sim 40 \%$ of the PACAP38 in the anterior pituitary gland, liver, spleen, and colon, PACAP27 is only a minor component of the total PACAP immunoreactivity for most other tissues. The lowest relative levels of PACAP27 levels are observed in the testes, where PACAP27 comprises $<1 \%$ of PACAP38. Because the PACAP receptor isoforms display specific patterns of secondmessenger activation that differ for the two peptides (Deutsch and Sun, 1992; Spengler et al., 1993; Rawlings, 1994; Rawlings and Hezareh, 1996), the relative equal abundance of PACAP27 and PACAP38 expressed by SCG neurons, combined with tissue-specific expression of receptor variants, will determine the sympathetic target responses. The exact physiological roles of PACAP27 versus PACAP38, however, remain to be established. The comparable levels of PACAP27 and PACAP38 in the SCG most likely reflect 
tissue-specific, endoproteolytic-processing events in sympathetic neurons. The tissue levels of PACAP27 cannot simply represent proteolytic breakdown of PACAP38, because the post-translational production of PACAP27 requires endoproteolytic cleavage at an internal paired basic amino acid site in the precursor molecule, removal of the carboxyl terminal basic amino acid, and $\alpha$-amidation of the resulting glycine-extended carboxyl terminus of the peptide. Several post-translational processing enzymes involved in the biosynthesis of neuropeptides, including amidating enzyme, PC1 (also called PC3) and PC2, have been identified in the SCG (Paquet et al., 1996; Braas and May, unpublished observation). The prevalence and activity of specific endoproteolytic enzymes at preferential precursor cleavage sites will undoubtedly determine the final bioactive PACAP peptide profile. Future biosynthetic labeling studies will be necessary to delineate the rate of pro-PACAP synthesis and ordered processing steps that result in the formation of the two bioactive peptides in sympathetic neurons.

The levels of PACAP in the SCG were approximately three orders of magnitude lower than NPY, which is the most abundant peptide identified in the sympathetic system, and approximately five orders of magnitude lower than ganglion catecholamine (Jarvi et al., 1986; Marek and Mains, 1989; May et al., 1995). Yet, SCG PACAP levels were high compared with galanin, substance P, or VIP. For example, adult SCG total PACAP immunoreactivity of $12 \mathrm{fmol} /$ ganglion was 6- to 25-fold greater than these other neuropeptides, which range from $\sim 0.5$ to 2 fmol of peptide/ ganglion (Rao et al., 1992a,b; Sun et al., 1992; Mohoney et al., 1994; Schreiber et al., 1994).

Ganglionic neuropeptides may arise from endogenous and/or exogenous sources. Fibers and a few neurons in the intact adult ganglion express VIP or galanin immunoreactivity, and substance $\mathrm{P}$ immunoreactivity is observed primarily in ganglion nerve fibers (Hokfelt et al., 1977a,b; Sasek and Zigmond, 1989). Recent PCR studies, however, have identified a regulated pool of mRNAs encoding these neuropeptides in the SCG (Rao et al., 1992b; Sun et al., 1992; Fann and Patterson, 1993; 1994; Mohney et al., 1994). In sharp contrast, NPY is localized to $\sim 60 \%$ of adult SCG principal neurons. Although preganglionic and sensory neuronal fibers may contribute to the pool of SCG PACAP immunoreactivity, a subpopulation of sympathetic neurons expressed both PACAP immunoreactivity and pro-PACAP mRNA (Beaudet et al., 1996; Klimaschewski et al., 1996; Sundler et al., 1996). Moreover, enriched sympathetic neurons cultured in defined medium in the absence of preganglionic and target influences expressed both PACAP immunoreactivity and pro-PACAP mRNA consistent with the endogenous production of PACAP peptides in vivo.

Numerous sympathetic neurophysiological processes can be modulated by elevated potassium. Chronic exposure to high potassium results in an initial and rapid cell depolarization, followed by a sustained rise in intracellular calcium caused by ion influx through voltage-gated calcium channels. Increased potassium prevents sympathetic neuron apoptosis, enhances postmitotic neuron development from progenitor sympathoadrenal cells, alters nicotinic receptor subunit expression, regulates neuropeptide and neurotransmitter production, and influences neurophenotypic expression (Rao et al., 1992a; Sun et al., 1992; Zigmond et al., 1992; Lewis et al., 1994; Verdi et al., 1994; DeKoninck and Cooper, 1995; Franklin et al., 1995; May et al., 1995). Similar to previous studies of other peptides, depolarization produced a sustained stimulation of PACAP release from cultured sympathetic neurons. The rate of PACAP secretion was increased more than 25 -fold over basal, similar to the $\sim 20$-fold depolarization- stimulated rate of NPY release (May et al., 1995). Cellular PACAP content and mRNA levels were elevated concomitantly with peptide secretion, again paralleling changes in other sympathetic neuropeptides; SCG substance P and VIP immunoreactivities increase 10- and 60-fold, respectively, after depolarization (Sun et al., 1992). Under identical conditions to those for depolarization-induced neuronal PACAP, both cellular content and rate of secretion of substance $\mathrm{P}, \mathrm{VIP}$, and galanin also are elevated dramatically; however, the magnitude of the increases is peptide specific (Braas et al., 1996). In comparison, SCG neuron catecholamine content and release increase only modestly in the presence of potassium. Furthermore, unlike other peptides in which content and release are concomitantly modulated, NPY release is elevated, whereas cellular NPY remains unaltered (May et al., 1995).

Unexpectedly, chronic depolarization not only induced the 2.2 $\mathrm{kb}$ form of PACAP mRNA, which is the predominant mRNA form in neuroendocrine tissues, but also a smaller $0.9 \mathrm{~kb}$ mRNA. Among the possibilities, the smaller mRNA form may represent the novel form of PACAP mRNA described previously in testes. This testicular variant is unique not only because of sequence truncation in the untranslated regions, but also because of the addition of a novel $126 \mathrm{bp}$ sequence at the $5^{\prime}$-end of the shorter transcript. This hypothesis was tested by reverse transcriptionPCR using primers specific to testicular PACAP; however, unlike the testes, cDNA from control and treated cultured SCG neurons failed to generate the anticipated amplified products. These results suggest that the shorter SCG PACAP mRNA does not possess the novel $5^{\prime}$-sequence and may instead be produced from possible alternative splicing or polyadenylation events. Sequence analysis of PACAP cDNA clones demonstrates the presence of multiple polyadenylation signal sequences capable of generating the shorter transcripts (Ogi et al., 1990; Ohkubo et al., 1992), which could play a role in altering PACAP mRNA stability in association with RNA-binding proteins. Extended 3'-untranslated regions have been associated with the destabilization of a number of different receptor and neurohormone mRNAs, including VIP (Levy and Hug, 1992; Mountford et al., 1992; Chew et al., 1994). Whether the shorter forms of PACAP mRNA confer some level of mRNA stability analogous to the multiple forms of VIP mRNA transcripts is unknown. The induction of both the 2.2 and $0.9 \mathrm{~kb}$ forms of PACAP mRNAs nevertheless seems to provide additional mechanisms for PACAP gene regulation and peptide production modulation in response to changing developmental or regulatory stimuli.

The functions of PACAP are multifaceted, encompassing endocrine, cardiovascular, and gastrointestinal tissues. In the nervous system, PACAP peptides produce dramatic changes in neuronal calcium flux, pheochromocytoma neurite outgrowth, neuroblast survival, and neurotransmitter and neuropeptide production (Deutsch and Sun, 1992; DiCicco-Bloom and Deutsch, 1992; Tatsuno et al., 1992; May and Braas, 1995). The projection sites of SCG neurons containing PACAP and the function of sympathetic PACAP peptides remain to be established. Because in some tissues, PACAP also has been localized to small populations of parasympathetic postganglionic neurons that differ from VIP-containing cells (Tobin et al., 1995), how PACAP in the two autonomic pathways participates in the neuroregulation of autonomic development and function will be of considerable interest.

The current studies do demonstrate clearly that PACAP represents one of several regulated peptidergic systems expressed in the SCG that participates in the plasticity of the sympathetic 
neuron phenotype. SCG neurons are principally catecholaminergic with the majority of the neuronal population coproducing NPY (Jarvi et al., 1986; Marek and Mains, 1989; May et al., 1995); however, smaller subsets of neurons contain other neuropeptides, including VIP, substance P, somatostatin, neurotensin, enkephalins, and calcitonin gene-related peptide (Hokfelt et al., 1977a,b; Schultzberg et al., 1979; Landis and Fredieu, 1986; Sasek and Zigmond, 1989; Landis, 1990). The signals and mechanisms that direct production of specific transmitter and peptide profiles in individual neurons are invariably complex and dictated by neuronal activity, developmental signals, and target tissue factors. The profile of sympathetic neuron peptides can be altered on presentation of inappropriate tissue targets to postganglionic projection fibers (Schotzinger and Landis, 1988; 1990). The neurophenotypic profile in the SCG can be modulated by decentralization and/or axotomy (Hyatt-Sachs et al., 1993; Rao et al., 1993; Mohney et al., 1994; Schreiber et al., 1994), depolarization (Rao et al., 1992a; Sun et al., 1992; Zigmond et al., 1992; Lewis et al., 1994; Sun et al., 1994; Verdi et al., 1994; DeKoninck and Cooper, 1995; Franklin et al., 1995; May et al., 1995), hormones, and neuropoietic cytokines (Nawa and Sah, 1990; Rao et al., 1992a; Patterson and Nawa, 1993; Fann and Patterson, 1994; Lewis et al., 1994; Pennica et al., 1995; Braas et al., 1996). The current studies have shown that PACAP peptides are integral components of SCG neurons that can be regulated at several independent sites along the peptide biosynthetic and secretory pathways. PACAP peptides have numerous actions as neurohormones, neurotransmitters, and neurotrophic factors and exhibit high potency at all of the PACAP-selective and VIP/PACAP receptors identified to date. In this regard, the expression of PACAP in the SCG may be especially pertinent in terms of the functional heterogeneity and diversity of sympathetic neurons and in the maintenance and regulation of autonomic neuronal development, function, and communication.

\section{REFERENCES}

Arimura A (1992) Receptors for pituitary adenylate cyclase-activating polypeptide: comparison with vasoactive intestinal peptide receptors. Trends Endocrinol Metab 3:288-294.

Arimura A, Somogyvari-Vigh A, Miyata A, Mizuno K, Coy DH, Kitada C (1991) Tissue distribution of PACAP as determined by RIA: highly abundant in the rat brain and testes. Endocrinology 129:2787-2789.

Beaudet M, Braas KM, May V (1996) Pituitary adenylate cyclase activating polypeptide (PACAP) expression in sympathetic preganglionic neurons innervating the superior cervical ganglion. Soc Neurosci Abstr 22:1998.

Bennett HPJ, Hudson AM, Kelly L, McMartin C, Purdon GE (1978) A rapid method, using octadecasilyl-silica, for extraction of certain peptides from tissues. Biochem J 175:1139-1141.

Bennett HPJ, Browne CA, Solomon CA (1981) Complete purification of pituitary peptides using reverse-phase HPLC alone. In: Peptides (Rich DH, Gross E, eds), pp 785-788. Rockford, IL: Pierce Chemical.

Braas KM, Childers SR, U'Prichard DC (1983) Induction of differentiation increases $\mathrm{Met}^{5}$-enkephalin and $\mathrm{Leu}^{5}$-enkephalin content in NG108-15 hybrid cells: an immunocytochemical and biochemical analysis. J Neurosci 3:1713-1727.

Braas KM, Harakall SH, Ouafik L'H, Eipper BA, May V (1992) Expression of peptidylglycine $\alpha$-amidating monooxygenase: an immunocytochemical and in situ hybridization study. Endocrinology 130:2778-2788.

Braas KM, Brandenburg CA, May V (1994a) Pituitary adenylate cyclase activating polypeptide regulation of AtT-20/D16v corticotrope cell proopiomelanocortin expression and secretion. Endocrinology 134: 186-195.

Braas KM, Hendley ED, May V (1994b) Anterior pituitary proopiomelanocortin expression is decreased in hypertensive rat strains. Endocrinology 134:196-205.

Braas KM, Harakall SA, May V (1996) Depolarization of sympathetic neurons elicits distinct modulation of NPY, substance P, VIP and galanin content, secretion and mRNA. Soc Neurosci Abstr 22:1764.

Chew L-J, Murphy D, Carter DA (1994) Alternatively polyadenylated vasoactive intestinal peptide mRNAs are differentially regulated at the level of stability. Mol Endocrinol 8:603-613.

DeKoninck P, Cooper E (1995) Differential regulation of neuronal nicotinic ACh receptor subunit genes in cultured neonatal rat sympathetic neurons: specific induction of $\alpha_{7}$ by membrane depolarization through $\mathrm{Ca}^{2+} /$ calmodulin-dependent kinase pathway. J Neurosci 15:7966-7978.

Deutsch PJ, Sun Y (1992) The 38-amino acid form of pituitary adenylate cyclase activating polypeptide stimulates dual signaling cascades in PC12 cells and promotes neurite outgrowth. J Biol Chem 267: 5108-5113.

DiCicco-Bloom E, Deutsch P (1992) Pituitary adenylate cyclase activating polypeptide (PACAP) potently stimulates mitosis, neuritogenesis and survival in cultured rat sympathetic neuroblasts. Regul Peptides 37:319.

Fann M-J, Patterson PH (1993) A novel approach to screen for cytokine effects on neuronal gene expression. J Neurochem 61:1349-1355.

Fann M-J, Patterson PH (1994) Neuropoietic cytokines and activin A differentially regulated the phenotype of cultured sympathetic neurons. Proc Natl Acad Sci USA 91:43-47.

Franklin JL, Sanz-Rodriguez C, Juhasz A, Deckwerth TL, Johnson Jr EM (1995) Chronic depolarization prevents programmed death of sympathetic neurons in vitro but does not support growth: requirement for $\mathrm{Ca}^{2+}$ influx but not Trk activation. J Neurosci 15:643-664.

Ghatei MA, Takahashi K, Suzuki Y, Gardiner J, Jones PM, Bloom SM (1993) Distribution, molecular characterization of pituitary adenylate cyclase-activating polypeptide and its precursor encoding messenger RNA in human and rat tissues. J Endocrinol 136:159-166.

Hannibal J, Mikkelsen JD, Fahrenkrug J, Larsen PJ (1995) Pituitary adenylate cyclase activating peptide gene expression in corticotropinreleasing factor-containing parvicellular neurons of the rat hypothalamic paraventricular nucleus is induced by colchicine, but not by adrenalectomy, acute osmotic, ether or restrain stress. Endocrinology 136:4116-4124.

Hashimoto H, Ishihara T, Shigemoto R, Mori K Nagata S (1993) Molecular cloning and tissue distribution of a receptor for pituitary adenylate cyclase activating polypeptide. Neuron 11:333-342.

Hokfelt T, Elfvin L-G, Schultzberg M, Fuxe K, Said SI, Mutt V (1977a) Immunohistochemical evidence of vasoactive intestinal polypeptidecontaining neurons and nerve fibers in sympathetic ganglia. Neuroscience 2:885-896.

Hokfelt T, Elfvin L-G, Schultzberg M, Goldstein M, Nilsson G (1977b) On the occurrence of substance $P$ fibers in sympathetic ganglia: immunohistochemical evidence. Brain Res 132:29-41.

Hosoya M, Onda H, Ogi K, Masuda Y, Miyamoto Y, Ohtaki T, Okazaki H, Arimura A, Fujino M (1993) Molecular cloning and functional expression of rat cDNAs encoding the receptor for pituitary adenylate cyclase activating polypeptide (PACAP). Biochem Biophys Res Commun 194:133-143.

Hurley JD, Gardiner JV, Jones PM, Bloom SR (1995) Cloning and molecular characterization of complementary deoxyribonucleic acid corresponding to a novel form of pituitary adenylate cyclase-activating polypeptide messenger ribonucleic acid in the rat testis. Endocrinology 136:550-557.

Hyatt-Sachs H, Schreiber RC, Bennett TA, Zigmond RE (1993) Phenotypic plasticity in adult sympathetic ganglia in vivo: effects of deafferentation and axotomy on the expression of vasoactive intestinal peptide. J Neurosci 13:1642-1653.

Inagaki N, Yoshida H, Mizuta M, Mizuno N, Fujii Y, Gonoi T, Miyazaki J-I, Seino S (1994) Cloning and functional characterization of a third pituitary adenylate cyclase-activating polypeptide receptor subtype expressed in insulin-secreting cells. Proc Natl Acad Sci USA 91:2679-2683.

Ishihara T, Shigemoto R, Takahasi K, Nagata S (1992) Functional expression and tissue distribution of a novel receptor for vasoactive intestinal peptide. Neuron 8:811-819.

Jarvi R, Helen P, Pelto-Huikko M, Hervonen A (1986) Neuropeptide Y(NPY-) like immunoreactivity in rat sympathetic neurons and small granule containing cells. Neurosci Lett 67:223-227.

Kessler JA (1984) Non-neuronal cell conditioned medium stimulates peptidergic expression in sympathetic and sensory neurons in vitro. Dev Biol 106:61-69.

Klimaschewski L, Hauser C, Heym C (1996) PACAP immunoreactivity 
in the rat superior cervical ganglion in comparison to VIP. NeuroReport 7:2797-2801.

Kobayashi H, Uezono Y, Ueno S, Izumi F (1994) Pituitary adenylate cyclase activating polypeptides (PACAPs) increase cAMP in rat cerebral microvessels. Brain Res 647:145-147.

Landis SC (1990) Target regulation of neurotransmitter phenotype. Trends Neurosci 13:344-350.

Landis SC, Fredieu JR (1986) Coexistence of calcitonin gene-related peptide and vasoactive intestinal peptide in cholinergic sympathetic innervation of rat sweat gland. Brain Res 377:177-181.

Levy JR, Hug V (1992) Regulation of insulin receptor gene expression: cell cycle-mediated effects on insulin receptor mRNA stability. J Biol Chem 267:25289-25295.

Lewis SE, Rao MS, Symes AJ, Dauer WT, Rink JS, Landis SC, Hyman SE (1994) Coordinate regulation of choline acetyltransferase, tyrosine hydroxylase, and neuropeptide mRNAs by ciliary neurotrophic factor and leukemia inhibitory factor in cultured sympathetic neurons. J Neurochem 63:429-438.

Lutz EM, Sheward WJ, West KM, Morrow JA, Fink G, Harmar AJ (1993) The $\mathrm{VIP}_{2}$ receptor: molecular characterization of a cDNA encoding a novel receptor for vasoactive intestinal peptide. FEBS Lett 334:3-8.

Marek KL, Mains RE (1989) Biosynthesis, development, and regulation of neuropeptide $\mathrm{Y}$ in superior cervical ganglion culture. J Neurochem 52:1807-1816.

May V, Eipper BA (1986) Long term culture of primary rat pituitary adrenocorticotropin/endorphin- producing cells in serum-free medium. Endocrinology 118:1284-1295.

May V, Braas KM (1995) Pituitary adenylate cyclase activating polypeptide (PACAP) regulation of sympathetic neuron neuropeptide $\mathrm{Y}$ and catecholamine expression. J Neurochem 65:978-987.

May V, Brandenburg CA, Braas KM (1995) Differential regulation of sympathetic neuron neuropeptide $\mathrm{Y}$ and catecholamine content and secretion. J Neurosci 15:4580-4591.

Miyata A, Arimura A, Dahl RR, Minamino N, Uehara A, Jiang L, Culler MD, Coy DH (1989) Isolation of a novel 38 residue-hypothalamic polypeptide which stimulates adenylate cyclase in pituitary cells. Biochem Biophys Res Commun 164:567-574.

Mohney RP, Siegel RE, Zigmond RE (1994) Galanin and vasoactive intestinal peptide mRNAs increase following axotomy of adult sympathetic neurons. J Neurobiol 25:108-118.

Morrow JA, Lutz EM, West KM, Fink G, Harmar AJ (1993) Molecular cloning and expression of a cDNA encoding a receptor for pituitary adenylate cyclase activating polypeptide (PACAP). FEBS Lett 329:99-105.

Mountford PS, Brandon MR, Adams TE (1992) Removal of 3' untranslated sequences dramatically enhances transient expression of ovine follicle-stimulating hormone beta messenger ribonucleic acid. J Neuroendocrinol 4:655-658.

Nawa H, Sah DW (1990) Different biological activities in conditioned media control the expression of a variety of neuropeptides in cultured sympathetic neurons. Neuron 4:279-287.

Nilsson SF (1994) PACAP-27 and PACAP-38: vascular effects in the eye and some other tissues in the rabbit. Eur J Pharmacol 253:17-25.

Nilsson SF, DeNeef P, Robberecht P, Christophe J (1994) Characterization of ocular receptors for pituitary adenylate cyclase activating polypeptide (PACAP) and their coupling to adenylate cyclase. Exp Eye Res 58:459-467.

Ogi K, Kimura C, Onda H, Arimura A, Fujino M (1990) Molecular cloning and characterization of cDNA for the precursor of rat pituitary adenylate cyclase activating polypeptide (PACAP). Biochem Biophys Res Commun 173:1271-1279.

Ohkubo S, Kimura C, Ogi K, Okazaki K, Hosoya M, Onda H, Miyata A, Arimura A, Fujino M (1992) Primary structure and characterization of the precursor to human pituitary adenylate cyclase activating polypeptide. DNA Cell Biol 11:21-30.

Paquet L, Massie B, Mains RE (1996) Proneuropeptide Y processing in large dense-core vesicles: manipulation of prohormone convertase expression in sympathetic neurons using adenoviruses. J Neurosci 16:964-973.

Patterson PH, Nawa H (1993) Neuronal differentiation factors/cytokines and synaptic plasticity. Cell 72/Neuron [Suppl] 10:123-137.

Pennica D, Shaw KJ, Swanson TA, Moore MW, Shelton DL, Zioncheck KA, Rosenthal A, Taga T, Paoni NF, Wood WI (1995) Cardiotro- phin-1: biological activities and binding to the leukemia inhibitory factor receptor/gp130 signaling complex. J Biol Chem 270:10915-10922.

Pisegna JR, Wank SA (1993) Molecular cloning and functional expression of the pituitary adenylate cyclase activating polypeptide type I receptor. Proc Natl Acad Sci USA 90:6345-6349.

Purves D, Rubin E, Snider WD, Lichtmann J (1986) Relation of animal size to convergence, divergence, and neuronal number in peripheral sympathetic pathways. J Neurosci 6:158-163.

Rao MS, Tyrrell S, Landis SC, Patterson PH (1992a) Effects of ciliary neurotrophic factor (CNTF) and depolarization on neuropeptide expression in cultured sympathetic neurons. Dev Biol 150:281-293.

Rao M, Patterson PH, Landis SC (1992b) Multiple cholinergic differentiation factors are present in footpad extracts: comparison with known cholinergic factors. Development 116:731-744.

Rao MS, Sun Y, Vaidyanathan U, Landis SC, Zigmond RE (1993) Regulation of substance $\mathrm{P}$ is similar to that of vasoactive intestinal peptide after axotomy or explantation of the rat superior cervical ganglion. J Neurobiol 24:571-580.

Rawlings SR (1994) PACAP receptors, and intracellular signalling. Mol Cell Endocrinol 101:C5-C9.

Rawlings SR, Hezareh M (1996) Pituitary adenylate cyclase-activating polypeptide (PACAP) and PACAP/vasoactive intestinal polypeptide receptors: actions on the anterior pituitary gland. Endocr Rev 17:4-29.

Sasek CA, Zigmond RE (1989) Localization of vasoactive intestinal peptide- and peptide histidine isoleucine amide-like immunoreactivities in the rat superior cervical ganglion and its nerve trunks. J Comp Neurol 280:522-532.

Schotzinger RJ, Landis SC (1988) Cholinergic phenotype developed by noradrenergic sympathetic neurons after innervation of a novel cholinergic target in vivo. Nature 335:637-639.

Schotzinger RJ, Landis SC (1990) Acquisition of cholinergic and peptidergic properties by the sympathetic innervation of rat sweat glands requires interactions with normal target. Neuron 5:91-100.

Schreiber RC, Hyatt-Sachs H, Bennett TA, Zigmond RE (1994) Galanin expression increases in adult rat sympathetic neurons after axotomy. Neuroscience 60:17-27.

Schultzberg M, Hokfelt T, Terenius L, Elfvin L, Lundberg JM, Brandt J, Elde RP, Goldstein M (1979) Enkephalin immunoreactive nerve fibers and cell bodies in sympathetic ganglia of the guinea pig and rat. Neuroscience 4:249-270.

Simmoneaux V, Ouichou A, Pevet P (1993) Pituitary adenylate cyclase activating polypeptide (PACAP) stimulates melatonin synthesis from rat pineal gland. Brain Res 603:148-152.

Spengler D, Waeber C, Pantaloni C, Holsboer F, Bokaert J, Seeburg PH, Journot L (1993) Differential signal transduction by five splice variants of the PACAP receptor. Nature 365:170-175.

Sun Y, Rao MS, Landis SC, Zigmond RE (1992) Depolarization increases vasoactive intestinal peptide- and substance P-like immunoreactivities in cultured neonatal and adult sympathetic neurons. J Neurosci 12:3717-3728.

Sundler F, Ekblad E, Hannibal J, Moller K, Zhang Y-Z, Mulder H, Elsas T, Grunditz T, Danielsen N, Fahrenkrug J, Uddman R (1996) Pituitary adenylate cyclase activating polypeptide in sensory and autonomic ganglia: localization and regulation. Ann NY Acad Sci 805:410-428.

Svoboda M, Tastenoy M, Ciccarelli E, Stievenart M, Christophe J (1993) Cloning of a splice variant of the pituitary adenylate cyclase activating polypeptide (PACAP) type I receptor. Biochem Biophys Res Commun 195:881-888.

Tatsuno I, Yada T, Vigh S, Hidaka H, Arimura A (1992) Pituitary adenylate cyclase activating polypeptide and vasoactive intestinal peptide increase cytosolic free calcium concentrations in cultured rat hippocampal neurons. Endocrinology 131:73-81.

Tobin G, Asztely A, Edwards AV, Ekstrom J, Hakanson R, Sundler F (1995) Presence and effects of pituitary adenylate cyclase activating peptide in the submandibular gland of the ferret. Neuroscience 66:227-235.

Verdi JM, Ip N, Yancopoulos GD, Anderson DJ (1994) Expression of trk in MAH cells lacking the p75 low-affinity nerve growth factor receptor is sufficient to permit nerve growth factor-induced differentiation to postmitotic neurons. Proc Natl Acad Sci USA 91:3949-3953.

Zigmond RE, Hyatt-Sachs H, Baldwin C, Qu XM, McKeon TW, Schreiber RC, Vaidyanathan U (1992) Phenotypic plasticity in adult sympathetic neurons: changes in neuropeptide expression in organ culture. Proc Natl Acad Sci USA 89:1507-1511. 